\title{
THE LANGUAGE AND IDEOLOGY OF CAPITAL PUNISHMENT FOR DRUG CONVICTS FOUND IN SELECTED OPINIONS IN THE JAKARTA POST
}

\author{
Arina Isti’anah \\ arina@usd.ac.id \\ English Letters, Faculty of Letters, Sanata Dharma University, \\ Indonesia
}

\begin{abstract}
This research is an investigation into the language use in people's opinions of capital punishment for drug convicts in The Jakarta Post. Capital punishment was executed to six drug convicts on January $18^{\text {th }}, 2015$. Controversy about this action has risen before and after the execution. People give their opinions in social media, such as Facebook, Twitter, blogs, and newspapers. The Jakarta Post is a well-known English newspaper in Indonesia which has a lot of readers. People choose this newspaper to convey their ideas so that their opinions will be read by people around the world. As the issue about capital punishment is popular recently, this research attempts at finding out people's ideology about capital punishment for drug convicts. Critical discourse analysis was conducted in this research as an approach to figure out how language use by the people can reveal their ideology of capital punishment. This research focused on observing four opinions of capital punishment for drug convicts in The Jakarta Post. The analysis shows that material processes dominate the opinions, followed by relational, mental and verbal processes. The ideologies revealed in the opinions are power, pessimism, and criticism. Before the execution, pessimism dominates the opinions, while after the execution criticism appears most in the opinions.
\end{abstract}

Key words: language, ideology, critical discourse analysis, capital punishment, power, pessimism, criticism

Abstrak: Penelitian ini merupakan sebuah investigasi terhadap penggunaan bahasa dalam opini masyarakat mengenai hukuman mati 
terhadap narapidana narkoba di The Jakarta Post. Hukuman mati baru saja diberikan kepada narapidana narkoba pada 18 Januari 2015. Banyak kontroversi yang muncul baik sebelum maupun sesudah eksekusi tersebut. Masyarakat memberikan pendapat mereka di media sosial seperti Facebook, twitter, weblog, dan suratkabar. The Jakarta Post merupakan surat kabar berbahasa Inggris yang cukup terkenal di Indonesia dan mempunyai banyak pembaca. Penulis di kolom opini memilih surat kabar ini agar tulisanmereka dapat dibaca oleh orang-orang di seluruh dunia. Karena isu tentang hukuman mati populer belakangan ini, penelitian ini mencoba untuk menemukan ideologi masyarakat mengenai hukuman mati pada narapida nanarkoba. Penelitian ini menggunakan pendekatan Analisis Wacana Kritis untuk mengungkapkan bagaimana penggunaan bahasa oleh masyarakat dapat menunjukkan ideologi mereka mengenai hukuman mati.Penelitian ini terfokus pada empat artikel mengenai hukuman mati yang ada di kolom opini di The Jakarta Post. Berdasarkan analisis yang telah dilakukan, proses material mendominasi opini masyarakat, diikuti oleh proses relasional, mental, dan verbal. Ideologi yang muncul adalah kekuatan, pesimisme, dan kritik. Sebelum eksekusi mati, pesimisme mendominasi opini masyarakat, sedangkan setelah eksekusi didominasi oleh kritik.

Kata kunci: bahasa, ideologi, analisis wacana kritis, hukuman mati, kekuasaan, pesimisme, kritik

\section{INTRODUCTION}

Drug abuse and addiction are serious problems as they destroy human beings. It does not only create injuries but also health and behavioral problems. Drug addiction is also risky for pregnant women and their babies. Some drugs can cause a baby to be born too small or too soon, or to have withdrawal symptoms, birth defects on learning and behavioral problems (recovergateway.org/substance-abuse-resources/drug-addiction-effects/).

Indonesia is recorded as a country which has a high percentage of drug abuse and addiction. The National Narcotics Agency (BNN) mentions that there are 4.5 million drug users in Indonesia, 22\% of those are students and $70 \%$ are workers (www.bbc.com). Students, housewives, artists, office or independent workers, politicians, even athletes cannot be separated from drug abuse. Consequently, the Indonesian government has decided to solve this case by giving capital punishment to the convicts, particularly dealers. 
Recently, capital punishment was executed to six drug dealers: each of them came from Brazil, Nigeria, Netherlands, Malawi, Vietnam, and Indonesia. People started to comment the issue in various media, such as Facebook, Twitter, blogs, and newspapers. Online media are seen as the suitable place to convey their ideas in different perspectives. The Jakarta Post is an online and printed English newspaper in Indonesia. To convey their opinions, people can write their ideas in the opinion columns. The columns can be accessed easily by the readers.

The popularity of the newspaper and its easy access motivate this research. Language use in opinion can greatly influence readers. People can convey their ideologies through the choice of words. To comprehend the ideology, language study is necessary to conduct as ideology is constructed and conveyed by symbolic forms of various kinds (Thompson in Wodak \& Meyer, 2001). People cannot perceive or interpret a social group's ideology by giving free judgment. Proofs on language choice must be discussed thoroughly to avoid misleading interpretations.

In order to achieve critical interpretations on a text, Critical Discourse Analysis (CDA) provides tools to criticize texts. CDA believes that text and talk play a key role in maintaining and legitimizing inequality, injustice, and oppression on society (Leeuwen in Renkema, 2009, p. 277). To prove the previous statement, Halliday's Systemic Functional Linguistics (SFL) is believed to provide the fundamental insight that made it possible to move linguistic analysis beyond formal description and use it as a basis for social critique (Leeuwen in Renkema, 2009, p. 279).

SFL proposes that meanings are represented through ideational (field), interpersonal (tenor), and textual (mode) functions: language is to represent the speaker's experience of the real world, to enact social relations with the addressee and to relate text to context (Yang in Renkema, 2009, p. 158). Ideational function is found by conducting transitivity analysis. By doing so, people's support or disapproval of capital punishment for drug convicts can be seen clearly through the representation of the participants in the clause.

Motivated by the above background, this research intends to achieve two purposes. The first purpose is to figure out the language use in the opinions. The language use in the opinion is described in terms of the participants in the clauses of the text. Manan asserts, "Transitivity is the very foundation of representation as it enables the analysis and interpretation of a particular event or situation in different ways (2001, p. 38)." Transitivity is able to describe the 
role of its participant in each clause from the process occurring there. Each process in transitivity analysis shows how language users relate themselves to the real world.

The second purpose is to find out the ideologies brought by the opinions of capital punishment for drug convicts. The findings of language use in the opinions become the tools to interpret the ideology in the opinions. Ideology can never be very far away from analysis of the words (Carter \& Simpson, 2005, p. 14). The choice of words in the data is able to derive how people convey their ideologies of certain cases through the choice of process, participants, and circumstances in the clauses.

This article is expected to give some benefits for the readers, particularly language researchers. This research proves that CDA enables the language researchers to criticize certain issues in a society. CDA is applicable to observe language use in politics, economics, educations, or literature. This research enriches the application of CDA in a social issue, capital punishment for drug convicts. This research is believed to also give insight for linguists who have passion in investigating language use in various social phenomena.

Another benefit is, by describing language use in certain issues, critical interpretation of it can be reached. The power of media to wrap certain issues in their language greatly influences people's mind. As a result, distorted opinions may happen. This research depicts how the critical observation on language use can avoid the previous assumption. Those interested in CDA can use the findings of this research as a comparison on similar topics or methods. Consequently, deeper understanding on CDA can occur since academicians have more topics to compare.

\section{LITERATURE REVIEW}

\section{A. Language and ideology}

Ideology is the message or meanings which are found in language. Ideology could be argued as how social relationships are shown in analysis (Fairclough, 1995). Furthermore, Fairclough (1995) clarifies that in the analysis of a language, ideology exists in various ways at various levels. Ideology should be located both in the structure and discursive events. In the structure level, it constitutes the outcome of past events and the conditions for current events. 
On the other hand, in discursive events, ideology reproduces and transforms its conditioning structure.

Ideology reveals the implicit and explicit meanings of the language use. Meanwhile, Wodak (2007) clarifies that ideology is equated with intended or non-intended meanings, with illocutionary and perlocutionary forces. Ideology enables the readers of the analysis react differently. However, ideology makes itself felt in a language even though there may not becontradictions

Thompson (1990) in Wodak and Meyer (2001) points out that ideology is the study of the ways in which meaning is constructed and conveyed by symbolic forms of various kinds. In conclusion, Wodak and Meyer (2001) say that ideology is the basic social representations of social groups. It has a schematic structure that represents the self-image of each group, featuring membership devices, aims, activities, norms, and resources of each group. In sum, ideology can be defined as both intended and extended meanings interpreted from language choice in a text.

B. Systemic Functional Linguistics (SFL) and Critical Discourse Analysis (CDA)

SFL and CDA are closely related to one another. Young and Harrison (2004) identify that both SFL and CDA share some unities: they share a view of language as a social construct, language influence the contexts and vice versa, and they emphasize the cultural and historical aspects of meaning (1). The meaning of language cannot be separated from its contexts. SFL propose the two contexts in which language is influenced.

SFL treats language as a means to convey people's ideas in various ways and purposes by means of wordings (Mathiessen and Halliday, 1997). To create meanings grammar can be represented within metafunctions: ideational (field), interpersonal (tenor), and textual function (mode). The first metafunction, ideational, includes the language users' experience of the internal world of their consciousness through their reactions, cognitions, and perceptions, and also their linguistic acts of speaking and understanding (Halliday, 2004).

To figure out how language users relate their experience to the real world, transitivity analysis is offered. Morley (2000) asserts that transitivity aims at identifying the participants or things which are involved, the actions and event taking place, and any relevant surrounding circumstances. There are six 
processes in the ideational function, namely material, mental, verbal, relational, behavioral and existential processes.

Research on language and ideology has been conducted by many scholars. Isti'anah observed language use by people to comment the issue on the Jakarta governor election (2014). The research concludes that most opinions utilized material processes to show what Jakarta people expect from the governor, reflected by Actor-Goal, Affected, and Goal-Recipient participants. Manan conducts similar research to find out how newspaper brings its ideology of Anwar and the reformation (2001). The research finds out that Anwar is portrayed as a powerful figure in Malaysia. It also concludes that language in the media has an important role in the construction of social reality. The previous studies prove that CDA can be applied to criticize social issues.

\section{METHODOLOGY}

This research observed the language and ideology of capital punishment for drug convicts in selected opinions in The Jakarta Post. There were four selected opinions talking about capital punishment for drug convicts, two of which were published before January 18, 2015 and the two others after the execution. The Jakarta Post was chosen as the source of the data since that newspaper can be accessed easily on the internet. As a consequence, the newspaper has a great power to influence the readers' mind on a certain issue as it can be accessed easily from people's gadget. The approach to observe the data above was Critical Discourse Analysis. Baxter mentions that in language study, CDA enables language scholars to observe how features of grammar work ideologically within individual texts to undermine oppressed groups (cited in Litosseli, 2010, p. 127). The observation of word choice enables the researcher to determine what process happens in the text. Fairclough (2006) clarifies that the critical approach in CDA is able to show how discourse is shaped by relations of power and ideologies, and the constructive effects discourse has upon social identities, social relations and systems of knowledge and belief, neither of which is normally apparent to discourse participants ( $p$. 12).

This research is in an attempt to find out how the choice of lexical and grammatical features in the opinion reveals people's ideologies towards the issue of capital punishment of drug convicts. As an example, one of the clauses 
in the data is "Indonesia (Actor) is among the few countries with the harshest drug laws, executing drug traffickers (Goal) to create a deterrent effect." The lexical choice "execute" marks the existence of a material process. The process is done by the powerful figure, or an Actor, in this case, "Indonesia". The action "execute" is done towards another participant, which is called a Goal, "drug traffickers". Such analysis is able to reveal poweras the ideology brought by the clause. Power, in the clause, is revealed through the material verb done by the Actor. This choice is also able to influence the readers' mind that Indonesia is a country which is eager to punish the traffickers for the sake of its integrity. For the procedures, each opinion was broken down into its clauses, thus analyzed using transitivity analysis. The findings of processes, participants, and circumstances in each opinion were, then, put in a table and presented in percentage. This article also discusses how certain choice of processes in the data can bring different ideologies and how different ideologies can be revealed by the same process.

\section{FINDINGS}

Based on the analysis of the data, there were 108 clauses found in the four articles containing opinions related to capital punishment. Before January 18,2005 , there were 50 clauses talking about capital punishment, while after January 18, 2015, there were 58 clauses talking about it. The two periods have the similarity of the choice of processes: dominated by material processes, followed by relational processes. The table below displays the findings.

Table 1:

Summary of Processes in the Opinions

before and after January 18, 2015

\begin{tabular}{|c|l|c|c|c|c|}
\hline \multirow{2}{*}{ No } & \multirow{2}{*}{ Processes } & \multicolumn{2}{|c|}{ Before } & \multicolumn{2}{c|}{ After } \\
\cline { 3 - 6 } & & January 18, 2015 & \multicolumn{2}{c|}{ January 18, 2015 } \\
\cline { 3 - 6 } & No & $\%$ & No & $\%$ \\
\hline 1 & Material & 29 & 58 & 29 & 50 \\
\hline 2 & Relational & 18 & 36 & 27 & 46 \\
\hline 3 & Mental & 2 & 4 & 1 & 2 \\
\hline 4 & Verbal & 1 & 2 & 1 & 2 \\
\hline \multicolumn{2}{r}{ Total } & 50 & 100 & 58 & 100 \\
\hline
\end{tabular}


The table above shows that there are no significant percentage differences on the use of language choice in the opinions before and after January 18,2015 . Before January 18 , material processes are used in $58 \%$, while after January 18, the same processes are used in $50 \%$. For relational processes, they are used in 36\% before January 18 and $46 \%$ after January 18 . The last two processes, mental and verbal processes, are used $4 \%$ and $2 \%$ in the opinions before January 18 , and are exercised in $2 \%$ for verbal processes in both before and after January 18.

The material processes utilize different appearance of participants in the clause. Material processes refer to the process of doing or happening. The clauses below display the use of Actor-Goal participants.

(1) In 2008, Indonesia (Actor) executed two drug traffickers (Goal) and in 2013, it (Actor) executed one more drug trafficker (Goal). (www.thejakartapost.com)

(2) For the convicts, all Indonesian nationals, Jokowi's compassion (Actor) would have saved their lives (Goal) since they were sentenced to death for premeditated murder and drug trafficking. (www.thejakartapost.com)

(3) Jokowi (Actor) has proven himself (Goal) to be an assertive leader true to his words and intentions. (www.the jakartapost.com)

The material verbs in clauses 1 to 3 require two participants, Actor and Goal. The verbs "execute", "save", and "prove" are included as transitive verbs that require an object. The object in clauses 1-3 are categorized as a Goal. A Goal receives an action done by an Actor.

Another variation use of participants in material processes are Actor, Goal, and Affected.

(4) ...that those most deserving of the death sentence under our laws (Actor) can escape, as long as they diligently grease the palms of the law enforcers. (www.thejakartapost.com)

(5) They (Goal) will less likely be caught shooting up, or perspiring near customs officers like the drug mules. (www.thejakartapost.com)

(6) ....and the drugs (Affected) are confiscated. (www.thejakartapost.com)

A material process enables a single participant. An Actor can stand as the only participant as in clause 4. It is possible as the material verb "escape" refers to "happening" rather than "doing". The different participant can be found in 
clause 5 which has a Goal as the participant. A Goal can stand alone in passive. A similar analysis also occurs in clause 6. There is an Affected in 6, which is also in passive.

In the relational processes, there are three variation uses of participants. Below are the findings:

(7) Hence, the argument that death penalty carries a deterrence effect (Carrier) is implausible (Attribute). (www.thejakartapost.com)

(8) However, he (Carrier) is a pragmatic politician and bureaucrat, not the idealist with visionary grand concepts that some have made him out to be (Attribute). (www.thejakartapost.com)

A relational process entails intransitive verbs and verbs indicating possessive or circumstantial relations (Manan, 2001, p. 39). The relational process in clauses 7 and 8 has Carrier and Attribute participants. In clause 7, the Carrier is attached to its Attribute, and the clause cannot be passivized. The Carrier is in the form of a noun phrase (NP) and the Attribute is an adjective. Similar to clause 7, clause 8 also has an NP as the Carrier and another NP as its Attribute. The head of Attribute in 8 is "politician"and "bureaucrat". This type of relational process is called an Attributive relational process marked by "to be"and "linking verbs"as its verb (Isti'anah, 2012, p. 28).

\section{A different type of a relational process is found in clause 9.}

(9) In current conditions, we (Possessor) have little clout in speaking up for over 200 citizens on death row abroad (Possessed). (www.thejakartapost.com)

The participants there are not Carrier-Attribute, but Possessor-Possessed. This type of relational process is called possessive relational process, marked by verbs "have" and its synonyms. A Possessor is the NP which owns a Possessed, which is also an NP. The head of the Possessed in clause 9 is "clout".

The use of mental processes is found in the following clauses:

(10) Jokowi (Sensor) wants to project an image of firmness in upholding the law (Phenomenon). (www.thejakartapost.com) 
(11) Experts and policymakers, Jokowi (Sensor) included, believe capital punishment serves as an effective deterrence against crime (Phenomenon). (www.thejakartapost.com)

(12) Millions of citizens (Sensor) are satisfied with the announcement of the executions (Phenomenon). (www.thejakartapost.com)

In clauses above, the mental process is marked by the verbs "want", "believe", and "satisfied". In clause 10, the mental verb is categorized as a volition verb. In clause 11, the mental verb is said as a cognition verb, while in clause 12 the mental verb is called an affection verb. The mental verbs in clauses 10 to 12 are different, but the clauses have the same participants, Senser-Phenomenon. A Sensor is the participant who senses or feels, while a Phenomenon is the participant which is felt. The Sensors in clauses 10 to 12 are realized in a form of an NP and so is the Phenomenon of clause 11. The Phenonemon in clauses 10 and 12 are in the form of a prepositional phrase (PP).

The other process in the opinions is verbal processes. The processes can be seen below.

(13) Jokowi (Sayer) says he will not pardon almost 60 other drug convicts on death row either (Verbiage). (www.thejakartapost.com)

(14) Many of his policies and actions in these past three months (Sayer), excluding the "big-mother" drama alluding to the influence of his patron speak of a leader who is not easily pressured by either domestic public opinion or international pressure. (www.the jakartapost.com)

A verbal process is a process of saying. This process has Sayer and Verbiage participants. A Sayer is the participant who says, marked by an NP. In clauses 13 and 14, the Sayer is realized by an NP. In clause 13, the Verbiage is the form of a Noun Clause (NC). An NC can be put in the Verbiage position as it has the same function as an NP. In clause 14, the Verbiage is in the form of a PP modified by a NC. However, the verbiage here also refers to the Sayer itself.

The paragraphs above demonstrate that language users have freedom to convey their meanings by the choice of wordings. The same process can be realized through various ways. Different verbs determine processes, thus participants in the texts. The analysis illustrated above also proves that language scholars are able to find the ideologies of people towards certain issues. The analysis is needed so that objective interpretation can be made. 
From the analysis, there are three ideologies found: power, pessimism, and criticism. Each of which is discussed below.

Table 2:

Summary of Ideology in the Opinions before and after January 18, 2015

\begin{tabular}{|c|l|c|c|c|c|}
\hline \multirow{2}{*}{ No } & \multirow{2}{*}{ Ideology } & \multicolumn{2}{|c|}{ Before January 18,2015} & \multicolumn{2}{c|}{ After January 18,2015} \\
\cline { 3 - 6 } & & No & $\%$ & No & $\%$ \\
\hline 1 & Power & 17 & 34 & 6 & 10 \\
\hline 2 & Pessimism & 24 & 48 & 12 & 20 \\
\hline 3 & Criticism & 9 & 18 & 40 & 70 \\
\hline \multicolumn{2}{r|}{ Total } & 50 & 100 & 58 & 100 \\
\hline
\end{tabular}

Table 2 above depicts different ideologies which appear before and after the execution to the six drug convicts. Before January 18, 2005, the opinions are dominated by "pessimism", while after January 18, the opinions are dominated by "criticism". Before the execution, "pessimism" appears in almost a half of the total data, $48 \%$. On the other hand, "criticism"dominates the opinions published after the execution, realized in $70 \%$.

\section{A. Power}

Power is the first ideology found in the data. Power is shown in the data by the existence of different processes: material, mental, and verbal processes. Material processes are marked by the use of material verbs. As the dominating process in the data, this process is also realized in different ways. Below are the examples:

(15) Indonesia isamong the few countries with the harshest drug laws, executing drug traffickers to create a deterrent effect. (www.thejakartapost.com)

(16) The death penalty is retained because it is believed to have deterrence effect. (www.thejakartapost.com)

(17) Now Jokowi, just over two months into his term, has refused to grant clemency to five convicts and will also withhold it from nearly 60 others. (www.thejakartapost.com)

In the above clauses, the material process is marked by the verb "execute", meaning to kill someone as a legal punishment (Cambridge Advanced Leaner's 
Dictionary). The material process contains of Actor and Goal as its participant. In clause 15, the Actor is "Indonesia" and the Goal is "drugtraffickers". Another participant is Circumstance, "to create a deterrent effect". The choice of Actor in clause 15, which is a country facing a big problem of drug abuse reveals that Indonesia has a power to punish the traffickers. The punishment is expected to give a 'lesson' to the citizens.

The material process in clause 16 above is marked by the verb "retained". However, the participants in clause 16 are different from the ones in clause 15. In clause 16, the participants are Affected and Circumstance. "The death penalty" is the Affected, as the verb "retain" is realized in passive clause. "Retain" is regarded as happening process as it does not always involve the Actor's role. In other words, Affected can be the only participant is the clause, excluding Circumstance, in passive clause. The Circumstance in clause 16 shows reason. The existence of the circumstance in clause 16 gives further understanding why the Affected is chosen. The Actor in clause 16 is unnecessary to mention as it is already clear that the one having power to punish the traffickers is Indonesia.

"Power" is also revealed in clause 17. In clause 17, the Actor is an NP, Jokowi. The choice of an Actor reveals that people regards Jokowi as a powerful figure who has the authority to "refuse" the Goal. The material process in clause 17 is included as a process of doing in the form of a transitive verb, which needs another participant. The Goal in 17 is realized in a PP. The existence of the Goal in clause 17 also indicates the president's power to reject the drug convicts' clemency.

"Power" is also shown in the mental and verbal processes. Below are the clauses:

(18) Experts and policymakers, Jokowi included, believe capital punishment serves as an effective deterrence against crime. (www.thejakartapost.com)

(19) Many of his policies and actions in these past three months, excluding the "big-mother" drama alluding to the influence of his patron, speak of a leader who is not easily pressured by either domestic public opinion or international pressure. (www.thejakartapost.com) 
"Power" is revealed in clause 18 by the choice of its participant. In clause 18, Jokowi acts as a Senoer who tries to influence people about his intention to eradicate drug abuse in Indonesia. Here, he is portrayed as a powerful figure who chooses capital punishment as the best way to solve the massive effect of drug abuse. Similar to clause 18, clause 19 also shows Jokowi's power as the president. However, "power" is realized by the different process. The verbal process here has a Verbiage which refers to the Sayer itself. Such phenomenon occurs as the language user intends to stress the power of Jokowi's policies and actions, shown by the Sayer.

\section{B. Pessimism}

The second ideology found in the data is "pessimism". "Pessimism" is first revealed by the material processes. Below are the examples.

(20) Jokowi, however, has apparently failed to learn from the past. (www.thejakartapost.com)

(21) Similar to reports of new recruits to extremist movements, the death penalty has not deterred extreme jihadists. (www.thejakarta post.com)

(22) ...that those most deserving of the death sentence under our laws can escape, as long as they diligently grease the palms of the law enforcers. (www.thejakartapost.com)

In clause 20, the material process is marked by the verb "fail". The Actor of clause 20 is Jokowi and the Goal is "to learn from the past". The president's failure to learn from the past is seen as people's pessimism towards the president to solve the massive effect of drug abuse in Indonesia.

Similar to clause 20, clause 21 also shows pessimism using material process, marked by the verb "deter". The verb is modified by a negation "not", whose Actor is "the death penalty". The Goal in clause 21 is an NP, extreme jihadists. People think that terrorism, done by extreme jihadists, is not comparable to drug abuse. The death penalty for extreme jihadists is tolerable, while drug abuse is seen as a different case. Extreme jihadists do not have any access to enable corruption. On the other hand, drug abuse is closely related to another criminal case. What people expect to eradicate is not drug abuse itself, but also it's surrounding affects. 
"Pessimism" is also shown by material process which has an Actor participant. The Actor in clause 22 is an NP, "those most deserving of the death sentence under our laws". The material verb "escape" is categorized as a verb of happening rather than doing. Therefore, the clause does not need a Goal. "Pessimism" is revealed by the verb "escape". The Actor is able to do the action as negation is empty there. The circumstance of condition can be found in clause 22, "as long as they diligently grease the palms of the law enforcements". People are not only pessimistic about President's ability to solve the problem, but also the law enforcements.

Besides material processes, "pessimism" is also revealed in relational processes. Below are the examples.

(23) Labeling drug trafficking as an extraordinary crime is groundless from the perspective of international law. (www.thejakar tapost.com)

(24) The intention that the death penalty will get rid of drug traffickers is therefore not achievable.... (www.thejakartapost.com)

(25) As the above arguments demonstrate, the death penalty is ineffective for combating drug trafficking... (www.thejakar tapost.com)

In clause 23, the relational process is categorized as an Attributive relational process. The Carrier is the NP, "labeling drug trafficking as an extraordinary crime", which is attached to its Attribute, "groundless from the perspective of international law". The government actually expects that Indonesian citizens support its sentencing death to the drug convicts. However, the participants in clause 23 reveal that people are pessimistic about what the government has done. Drug abuse is as ordinary as other cases, so it does not need to involve the death penalty.

"Pessimism" also appears in clause 24. The Carrier is an NP, "the intention", which is modified by an NC, "that the death penalty will get rid of drug traffickers". The Attribute is an adjective, "achievable". The verb "to be" in clause 24 is modified by a negation, not, which also stresses "pessimism". In a relational process, Carrier is always attached to its Attribute. Therefore, by choosing this process, people are pessimistic about the government's decision to retain death penalty as the best punishment to its traffickers. 
In clause 25, "pessimism" is also shown by Carrier-Attribute relations. The Carrier in clause 25 is "the death penalty" and the Attribute is "ineffective". This process reveals people's pessimism about the death penalty as an effective way to eradicate drug abuse in Indonesia. The occurrence of a Circumstance of purpose "for combating drug trafficking" functions to modify the Attribute. This construction stresses "pessimism" that the death penalty will stop drug abuse. In the analysis, "pessimism" is mostly revealed by relational processes. It proves that the death penalty is not supported in Indonesia as the best policy to solve drug abuse.

\section{Criticism}

The last ideology found in the data is criticism. Criticism is revealed by material processes as seen in the examples below:

(26) The government's policy has been widely criticized internationally but has the near-unanimous support of the Indonesian public and politicians. (www.thejakartapost.com)

(27) The death penalty, and particularly the executions of drug traffickers by the government of President Joko "Jokowi" Widodo, has recently generated two vastly differing reactions. (www.thejakartapost.com)

(28) President Jokowi is indeed untainted by human rights violations. (www.thejakartapost.com)

The material process in clause 26 is passive. The participant is a Goal, "the government policy". This participant receives a material verb "criticize", described further by a circumstance of manner, "internationally". This choice of process reveals criticism as the actions of the government are not only paid attention to by its citizens, but also people throughout the world. While other countries eliminate the death penalty, Indonesia keeps it as an attempt to stop drug abuse. Criticism goes to the government led by Joko Widodo.

Criticism also appears in clause 27. The Actor in clause 27, "the death penalty", is modified by another NP, "and particularly the executions of drug traffickers by the government of President Joko "Jokowi" Widodo", which actually functions to strengthen the role of the Actor. An Actor is the participant which leads the action of doing, "generate". This construction reveals "criticism" as the president is also mentioned in the clause to modify the Actor. The Goal in clause 27 is also an NP, "two vastly differing reactions". 
The Goal also shows criticism as it becomes the effect of the president's policy about capital punishment to drug convicts.

Another way which reveals criticism is shown in clause 28. There, "President Jokowi" is realized as the Goal as the clause is passive. The Actor in clause 28 is an NP, "human right violations". The material verb "untainted" reveals criticism as it reflects that the president is not influenced by the issue of human right. What Jokowi is concerned about is the future of Indonesian citizens. Jokowi is not influenced by the opinions and demonstration related to his decision. He attempts at showing people around the world that Indonesia has its own law which must be respected, too. What he decides is criticized widely by people in the name of human rights.

The same ideology can be shown by different use of process. Through relational processes, criticism can be identified as seen below:

(29) In current conditions, we have little clout in speaking up for over 200 citizens on death row abroad. (www.thejakartapost.com)

(30) However, he is a pragmatic politician and bureaucrat, not the idealist with visionary grand concepts that some have made him out to be. (www.thejakartapost.com)

(31) ...his rejection of clemency for death-row inmates and today's line-up of executions is not uncharacteristic of his leadership. (www.thejakartapost.com)

In clause 29, the relational process is shown by Possessor-Possessed participants. "Criticism" is revealed through the lexical items "little clout", as the Possessed. Indirectly, the opinion criticizes the government which seems to close its "ears". What the government has decided of capital punishment is unchanged. The circumstance of time, "in current conditions",refers to Jokowi's presidential era. His era is different from previous, on which capital punishment can be "bargained". Another circumstance, in speaking up for over 200 citizens on death row abroad, is actually criticizing the upcoming effect faced by Indonesian citizens who were also sentenced death. The current government seems not to protect its own citizens. The relation to countries whose citizens are punished by death is also out of Jokowi's concern.

Similar to previous analysis, clauses 30 and 31 also criticize Jokowi. In clause 30, Jokowi is attached to an Attribute, "a pragmatic politician and bureaucrat", which is modified by another NP, "not the idealist with visionary 
grand concepts that some have made him out to be". Clause 31 also criticizes Jokowi's decision as an Attribute, "not uncharacteristic of his leadership". Both clauses reveal that Jokowi is actually open to criticisms, but what he promoted in his campaign about mental revolution "forces" him to retain the capital punishment execution. What is said in clause 31 clearly criticizes Jokowi's leadership as the president.

\section{CONCLUSION}

It is inevitable that capital punishment attracts people's eyes on it. The way people comment on the issues reflects the society. The massive effect of drug abuse in Indonesia cannot be ignored and has to be overcome seriously. This research finds that the capital punishment done in Jokowi's presidential era does not get sufficient support from the citizens. Pessimism which appears before the execution is the proof, presented in $48 \%$. After the execution, criticism follows, shown in $70 \%$. The findings reveal that Indonesian people are still concernedwith human rights issues. Besides, they also put attention to Indonesian relationswith other countries. Drug abuse is also seen as a crime which is closely related to corruption.-People criticize that the eradication of drug abuse should touch the law administers. People are still pessimistic that the "mental revolution" campaigned by Jokowi is only for partial matters, as power only appears in 10\% after the execution.

\section{REFERENCES}

Atmanta, D. (2014, December 21). View point: death penalty not always the best policy. Retrieved February 6, 2015 from The Jakarta Post www.the jakartapost.com.

Azhar, H. \& Nieves, A. (2014, January 30). Time to abolish the death penalty in Indonesia. Retrieved February 6, 2015 from The Jakarta Post: www.the jakartapost.com.

Butler, C. S. (2003). Structure and Function: A Guide to Three Major StructuralFunctional Theories. Amsterdam: Benjamin Publishing Company.

Carter, R. \& Simpson, P. (2005). Language, Discourse, and Literature. London: Routledge. 
Cunanan, B. T. (2011). Using transitivity as a framework in a stylistic analysis of Virginia Woolf's Old Mrs. Grey. In Asian EFL Journal Professional Teaching Article, 54, pp. 69-79.

Downing, A. \& Locke, P. (2006). English Grammar: A University Course, $2^{\text {nd }}$ ed. New York: Routledge.

Effects of drug abuse and addiction. Retrieved February 6, 2014 from Gateway Foundation: recovergateway.org/substance-abuse-resources/drug-addict ion-effects.

Eggins, S. (2004). An Introduction to Systemic Functional Linguistics, $2^{\text {nd }}$ ed. London: MPG Books Ltd, Bodmin, Cornwall.

Fairclough, N. (1995). Critical Discourse Analysis: The Critical Study of Language. New York: Longman Publishing.

Fairclough, N. (2006). Discourse and Social Change. Cambridge: Polity Press.

Gunawan, R. (2014, December 10). Death penalty does not deter drug traffickers. Retrieved February 6, 2015, from The Jakarta Post: www thejakartapost. com.

Halliday, M. A. K. \& Matthiessen, C. M. I. M. (2004). An Introduction to Functional Grammar, $3^{\text {rd }}$ ed. London: Hodder Education.

Isti'anah, A. (2012). Ideologies in Hosni Mubarak's and Muammar Qaddafi's translated speeches: critical discourse analysis. An unpublished thesis. Yogyakarta: Universitas Sanata Dharma.

Isti'anah, A. (2014). Transitivity analysis in four selected opinions about Jakarta's governor election. Phenomena, 14 (2), pp. 163-175.

Johnson, S. \& Milani, T. M. (2010). Language Ideologies and Media Discourse: Texts, Practices, Politics. New York: Continuum.

Locke, T. (2004). Critical Discourse Analysis. New York: Continuum International Publishing Group.

Litosseliti, L. (2010). Research Methods in Linguistics. London: Continuum International Publishing Group.

Manan, S. (2001). Re-reading the media: A stylistic analysis of Malaysian media coverage of Anwar and the reformasi movement. Asia Pacific Media Educator, 11 (4), pp. 34-54. 
Matthiessen, C. \& Halliday, M.A.K. (1997). Systemic Functional Grammar: A first step into the theory. Retrieved February 4, 2015 from http://web.mac.

com/cmatthie/iWeb/SMMGresources/Mendoza2006Course_Descripti on_files/SFG_FirstStep_1.pdf.

Metila, R. A. (2013). A discourse analysis of news headlines: diverse framing for a hostage-taking event. Asian Journal of Social Sciences and Humanities, 2 (2), pp.171-178.

Nurbiati, A. (2014, January 23). End death penalty, even if we're not all that humane. Retrieved February 6, 2015 from The Jakarta Post: www.thejakartapost.com.

Pengguna narkotika di Indonesia enggan direhabilitasi. (2014, January 27). Retrieved February 6, 2014 from BBC Indonesia: www.bbc.com.

Renkema, J. (2009). Discourse, of Course: an overview of research in discourse studies. Amsterdam: John Benjamins Publishing Company.

Taiwo, R. (2007). Language, ideology and power relations in Nigerian newspaper headlines. Nebula, 4 (1), pp. 218-245.

Wodak, R. \& Meyer, M. (2001). Methods of Critical Discourse Analysis. London: SAGE Publication.

Young, L. \& Harrison, C. (2004). Systemic Functional Linguistics and Critical Discourse Analysis: Studies in Social Science. London: Continuum.

\section{APPENDIX 1:}

Article published before January 18, 2015.

\section{Death penalty does not deter drug traffickers}

The Attorney Generals Office (AGO) has announced its plan to execute five people by the end of 2014: mostly drug traffickers.

Indonesia is among the few countries with the harshest drug laws, executing drug traffickers to create a deterrent effect.

However, Indonesia's position to retain the death penalty, particularly for drug offenses, is problematic. 
First, the Indonesian legal community often refers to drug trafficking as an "extraordinary crime", thereby justifying the extraordinary punishment of the death penalty.

However, labeling drug trafficking as an extraordinary crime is groundless from the perspective of international law.

Article 6 of the International Covenant on Civil and Political Rights (ICCPR) which Indonesia has ratified - states that for countries that have not yet abolished the death penalty, it may only be imposed for "the most serious crimes".

Various UN bodies, such as the UN High Commissioner for Human Rights, UN Human Rights Committee, UN Special Rapporteur for extrajudicial, summary or arbitrary executions killings and the UN Office on Drugs and Crime, have consistently asserted that drug offenses do not meet the threshold of "the most serious crimes" to which the death penalty may lawfully be applied. In his 2012 report to the UN General Assembly, the UN Special Rapporteur on extrajudicial killings stated that the death penalty should only be applied for offenses of intentional killings, based on the practices of retentionist states and the jurisprudence of the UN and other bodies.

In March 2014, the International Narcotics Control Board - the independent and quasi-judicial body for monitoring government compliance with the three international drug control conventions, of which Indonesia is a member, encouraged states to abolish the death penalty for drug-related offenses.

The 1988 Convention against Illicit Traffic in Narcotic Drugs and Psychotropic Substances does not recognize the concept of "extraordinary crimes" for drug offenses. The convention places drug offenses into two categories.

First, drug offenses of a "grave nature", such as the production, manufacturing and extraction of drugs.

Second, offenses that are "particularly serious", such as the involvement of organized criminal groups in the production of drugs.

The 1988 convention does not explicitly recognize the death penalty for drug offenses.

Therefore, from an international drug law and international human rights law perspective, categorizing drug trafficking as an "extraordinary crime" and applying the death penalty to drug offenses is indefensible. 
Second, the death penalty is retained because it is believed to have deterrence effect. This view is simply invalid. In 2008, Indonesia executed two drug traffickers and in 2013, it executed one more drug trafficker.

According to the 2012 death penalty report by the Harm Reduction International group, there were approximately 100 people on death row in Indonesia, including 58 drug traffickers.

According to the 2013 annual report of Indonesia's National Narcotics Agency (BNN), there were 260 drug traffickers arrested in 2013 - an increase from 157 people in 2011 and 202 people in 2012. These numbers suggest that while the death penalty is continuously imposed and executions are carried out, the crime of drug trafficking shows no sign of abating. It seems obvious that the death penalty does not deter drug traffickers.

Further, in the past few years there have been cases where drug traffickers were able to operate from inside the prison.

This indicates that they may not be afraid of the penalty because they can bribe prison officials and other law enforcers. Hence, the argument that death penalty carries a deterrence effect is implausible.

Third, it is also often argued that drug trafficking has fatal consequences for younger generations and therefore drug traffickers deserye to be sentenced to death. But as William Schabas - an international scholar on the death penalty - rightly points out, in most cases, the drug traffickers are arrested and the drugs are confiscated. Interdicting drugs before they reach the public means that the trafficker sentenced to death could not have sold the drugs nor could anyone else and, hence, no lives have been lost.

Fourth, the higher probability that a harsh sentence is to be passed down, the higher probability that corruption is involved.

It is widely known that the Indonesian legal system is tainted with corruption and bribery. In this corrupted legal environment, if a drug trafficker is arrested and punishable by the death sentence, he or she is ready to pay high sums to enforcers to avoid prosecution or seek lenient sentences.

Rich drug traffickers will likely be able to evade the death penalty while those who are poor and cannot afford to bribe will be the ones facing execution.

The intention that the death penalty will get rid of drug traffickersis therefore not achievable and the risk that the state executes the wrong person is higher. 
Fifth, organizations running illicit drug trafficking are involved in a complex network controlled by some powerful people. Those arrested are often just drug mules taking the greatest risks.

Imposing the death penalty on them will not deter the drug kingpins controlling the syndicate as they will continue to seek, groom and exploit vulnerable individuals to do the dirty jobs.

Illicit drug trafficking unquestionably has harmful effects on individuals and society. However, there is a common misconception that imposing the death penalty and executing those involved in drug trafficking is the magic formula to address this problem. As the above arguments demonstrate, the death penalty is ineffective for combating drug trafficking, and thus Indonesia must evaluate its strategy. Indonesia should probably start by evaluating its unrealistic "2015 Indonesia Drug Free" program. While drugs have negative impacts on human beings, drugs can be positive too, for the purposes of health, science and technology.

This means that we cannot live in a "drug-free world", but looking at Indonesia's stubbornness to retain the death penalty despite its useless effect, one would ask whether Indonesia is open and ready to evaluate its misguided beliefs.

\section{APPENDIX 2:}

Article published before January 18, 2015

\section{View Point: Death penalty not always the best policy}

For the umpteenth time the death penalty has sparked controversy in Indonesia. This time around it is President Joko "Jokowi" Widodo who restarted the nationwide debate after he refused to grant mercy to five convicts on death row, which means they face imminent execution by firing squad.

Cabinet Secretary Andi Widjajanto said Thursday the President had signed a regulation that stipulates his rejection of the convicts' plea for clemency.

For the convicts, all Indonesian nationals, Jokowi's compassion would have saved their lives since they were sentenced to death for premeditated murder and drug trafficking. Jokowi says he will not pardon almost 60 other drug convicts on death row either.

Jokowi must have listened to his aides, legal experts and human rights champions, as well as people's voices, before taking the tough decision. 
However, there are several push factors that might have driven him to set aside considerations of human rights.

First and foremost, it is already an open secret that drugs are accessible to everybody, including minors, a situation that Jokowi describes as a state of narcotics emergency facing the nation.

On Thursday the National Narcotics Agency (BNN) found meth and marijuana inside the campus of a university located near to the BNN headquarters in East Jakarta, prompting the agency to conduct more raids in other campuses.

The UN Office on Drugs and Crime (UNODC) says Indonesia is among the largest producers of methamphetamine. Indonesia ranked third in Asia after China and Thailand in terms of the amount of meth seized in 2012: 2.1 tons, which was triple the amount seized in 2008.

Second, narcotics pose a serious threat to Jokowi's much-vaunted mental revolution, which he envisions as a national character-building exercise to instill a new way of thinking and to encourage the adoption of positive values in all sectors. The mental revolution is supposed to induce healthy lifestyles and clear minds, which are required for national development. Drug addiction will, of course, sabotage the goals.

Many governments, including Indonesia, maintain death sentences for drug traffickers because of the moral decay they have inflicted on society, which amounts to a serious crime.

Third, drug-related crimes, as well as other crimes, have continued unabated in part because of poor law enforcement, which is evident in the involvement of law enforcers in the drug supply chain and the corrupt prison administrations that enable convicted drug lords to operate their businesses from behind bars.

For most Indonesians who are longing for tough law enforcement, Jokowi's merciless policy in the war on drugs looks to live up to their expectations.

The President has also showed bold enforcement of the law when he ordered the sinking of foreign boats caught poaching fish in Indonesian waters, which has been justified under the law since 2009 but never before carried out.

It is crystal clear that Jokowi wants to project an image of firmness in upholding the law. His support for the death sentence is just a logical consequence. Experts and policymakers, Jokowi included, believe capital punishment serves as an effective deterrence against crime. 
Weak, inconsistent law enforcement has becomea consistent threat to the rule of law in the country, as evident in public distrust for law enforcers and, hence, in widespread disobedience to the law.

Public defiance of the law is commonly visible on the streets, where motorists violate traffic rules at will because the offenses mostly go unpunished.

Jokowi could have been inspired by French philosopher Jean-Jacques Rousseau, an avid proponent of the death sentence.

In Rousseau's mind, wrongdoers were enemies of the state and violators of the social contract and therefore must either be exiled or put to death. A healthy state, he said, has few criminals.

In fact, the death penalty has remained in place in many democracies, including the US, which is why Indonesia has insisted on maintaining capital punishment as an instrument of deterrence, although that is not always the case.

The death penalty runs counter to Article 28A of the Constitution, which clearly stipulates the right to life and defends life as a fundamental human right that shall not be curtailed under any circumstance.

But this principle has been widely disregarded, including by the Constitutional Court as the defender of the Constitution. In 2009 the Court ruled that the right to life is not absolute and that capital punishment is a justified restriction of that right.

Jokowi, however, has apparently failed to learn from the past. The previous administration of president Susilo Bambang Yudhoyono helped at least 110 Indonesians escape the death penalty in China, Iran, Malaysia and Saudi Arabia, thanks in part to the unofficial moratorium on executions his government imposed between 2008 and 2012. Yudhoyono commuted the death sentences of a number of convicts, including foreign drug traffickers.

Yudhoyono's foreign minister Marty Natalegawa admitted Indonesians sentenced to death overseas had benefited from the practice. Marty said Indonesia would have found it difficult to convince the governments of foreign countries to reprieve Indonesian convicts on death row if Jakarta had failed to show mercy, too.

Before resuming executions in 2013, Yudhoyono had granted 19 of the 126 clemency pleas that he received since taking office in 2004.

Now Jokowi, just over two months into his term, has refused to grant clemency to five convicts and will also withhold it from nearly 60 others. 
In so doing Jokowi has put the lives of more than 100 Indonesian nationals currently facing death sentences overseas in danger.

Assuming that Jokowi knows well the risks of his decision, he must be ready to face public condemnation for failing to protect his people abroad.

\section{APPENDIX 3:}

Article published after January 18, 2015.

\section{End death penalty, even if we're not all that humane}

"Take not life, which God has made sacred, except by way of justice and law. Thus does He command you, so that you may learn wisdom."

This quote from the Koran is among the sources of Muslims' agreement here with Indonesia's capital punishment, despite wide criticism of the Criminal Code inherited from Dutch colonial times - and despite endless lambasting of the judiciary as being among the nation's foremost corrupt institutions.

Support for the death penalty also comes from many, regardless of religion, particularly for the crimes of terrorism and drug abuse, the latter given the real fear of anyone's youngsters being exposed to drug traffickers, from small-town alleys across the vast country, to the middle-class suburbs of the capital.

Families financially and emotionally drained by an addict are not the subject of daily headlines, but the sporadic, dramatic police raids and arrest of suspected abusers, producers and traffickers with large numbers of banned drugs invigorate the emotional push for strong government measures. And not many care to differentiate the drug user from the traffickers.

It is such fears and sentiments that make the concern of human rights activists ring hollow in society, even as stated by the UN special rapporteur for Indonesia, with a name unfortunately harking back to the old colonial land, Cornelis Flinterman, who recently visited the country: "Crimes involving narcotics cannot be considered the most serious crime for which the death penalty can be used as a legitimate penalty," he said.

Indonesian diplomats to ordinary citizens have dismissed such protests from the UN, the European Union, home governments of the executed and death-row convicts and global rights organizations. They have defended President Joko "Jokowi" Widodo, who has declared there will be no clemency for drug abuse convicts. Thus, at least 20 other drug convicts on death row can expect louder international solidarity for their fate, though with little empathy here. 
However, the appeal of, among others, the National Commission on Human Rights to end the death penalty in related laws apart from the Criminal Code should be supported; it isinevitable that Indonesia, which has adopted the universal human rights principles, acknowledges that the right to life is non-derogable.

True, many of us are notas humane as human rights activists - surely terrorists and traffickers deserve to be shot, as like murderers they have no respect for others' lives and continue to wreak damage and destruction from behind prison bars?

But the chronic problem of Indonesia being a destination, production center, apart from a hub, of drug trafficking shows law enforcement, including shooting convicts to death, has not solved the issue. Similar to reports of new recruits to extremist movements, the death penalty has not deterred extreme jihadists.

Support for capital punishment here for drug abusers is based on strong religious beliefs and the equally strong conviction that nothing less than killing perpetrators destroying our children and families will help reduce the crime.

Such convictions remain, even as reports reveal that the big fish remain untouchable, that small-scale abusers become recruited into smuggling rings in prison, and as cleaning the judiciary from corruption has not been able to catch up with daily, largescale graft across the legal system, from the police to the courts to prison wardens meaning that those most deserving of the death sentence under our laws can escape, as long as they diligently grease the palms of the law enforcers.

Millions of citizens are satisfied with the announcement of the executions, rather than giving convicts the comparable comfort of life-long imprisonment - but this is not upholding justice.

President Jokowi has successfully signaled his intent to uphold the law against drug smugglers. He could lead us a step forward in making drug abuse policies more effective and improve credibility in a judiciary that aims to deliver justice, including the heaviest penalties to those deserving them.

This is not to say that those executed on Sunday were innocent. But just because we cannot clean the judiciary fast enough compared to countries ranking much lower on global corruption index lists, does not mean we can take the fast lane and kill some convicts.

As a former trafficker told me, those who get arrested and jailed are just stupid. The real kings of the business diligently consort with law enforcers and stay clean of drug abuse themselves. They will less likely be caught shooting up, or perspiring near customs officers like the drug mules. 
160 Celt, Volume 15, Number 2, December 2015, pp. 134-164

In current conditions, we have little clout in speaking up for over 200 citizens on death row abroad.

At the very least President Jokowi needs to put a hold on death penalties - because the executions' message is notlaw enforcement and justice.

It is law enforcement, but still selective justice to those who didn't manage to escape the firing squad.

\section{APPENDIX 4:}

Article published after January 18, 2015

\section{Time to abolish the death penalty in Indonesia}

Last week, we learned that Lindsay Sandiford, a British citizen, was sentenced to death for drug trafficking charges by a Bali court. The prosecution asked for a 15-year sentence, but the judges decided instead to impose the maximum penalty: death.

In recent years, Indonesia had appeared to be shifting away from the death penalty, in line with the global trend toward abolition. No one has been executed here since 2008, and death sentences have dropped to just a handful annually.

This shift is visible in foreign diplomacy as well. For the first time last year, Indonesia changed its vote for a UN Moratorium on the Use of the Death Penalty from opposition to abstention. Indonesia's delegate stated on the record that the public debate on capital punishment in Indonesia was "ongoing, including concerning a possible moratorium".

The Denpasar District Court's action this week stands in stark contrast to Indonesia's stated and demonstrated policy to move away from the death penalty. This new death sentence should serve as the impetus for the complete abolition of the death penalty in Indonesia. More than two-thirds of the countries in the world have abolished the death penalty. The year 2013 should be the time for Indonesia to follow suit.

We should abolish the death penalty, first of all, because it is the right thing to do and would show the world that Indonesia is committed to the protection of human rights.

We should also abolish the death penalty so that we are no longer compared to other death penalty retainers, like the US, whose criminal justice systems are notoriously problematic and rife with errors.

The controversies surrounding death penalty cases in America are well-documented. 
In the US, two out of three death penalty cases are overturned on appeal for mistakes committed by lawyers, judges and investigating officials at the original trial.

Many Americans believe that innocent people have been executed in the US. The case of Carlos DeLuna, a man executed in Texas in 1989, has received a great deal of attention in the US because of a recent investigation that strongly indicated his innocence. A total of 142 prisoners have been exonerated from death row in the US since 1973.

Indonesia is not immune from these same concerns about executing the innocent. The case of Sengkon and Karta, who served six years in prison before they were declared innocent in 1980, is a bitter reminder that the law, as a man-made institution, is fallible.

Nations across the world are beginning to recognize that if they are to make a commitment to human rights, they must also make a commitment to the right to life by abolishing the death penalty.

Countries like the US may be willing to execute people who are innocent or who did not receive a fair trial. But Indonesia can and should do better. Indonesia should lead the way for Association of South East Asian Nations (ASEAN) member states and emerging global powers by abolishing the death penalty once and for all.

\section{Jokowi's stance on death penalty ignores unfairness}

The death penalty, and particularly the executions of drug traffickers by the government of President Joko "Jokowi" Widodo, have recently generated two vastly differing reactions.

The government's policy has been widely criticized internationally but has the nearunanimous support of the Indonesian public and politicians.

Regrettably, the only visible segment of the Indonesian public strongly opposed to the death penalty are the human rights activists.

In the sights for the next round of executions are two Australians, Andrew Chan and Myuran Sukumaran, leaders of the Bali Nine drug ring.

The stern and swift executions tell something of Jokowi'spPresidency and his leadership. It perhaps came as a shock to the international community, which had euphoric expectations of Jokowi when he won the presidency.

Many distant observers had unrealistic expectations that Jokowi as a "new" politician 
would strive for all the "good" things: clean government, effective bureaucracy, human rights and so on.

President Jokowi is indeed untainted by human rights violations, and seems to genuinely care for the welfare of his people.

However, he is a pragmatic politician and bureaucrat, not the idealist with visionary grand concepts that some have made him out to be.

As we have seen in the first three months of his presidency, in terms of policy and actions within his control, he lived upto his "packaging", including the expected tugof-war against the string-pulling of the old guard.

Disregarding the current mess caused by the oligarchs within his coalition on political appointments and the chief of police debacle, Jokowi has proven himself to be an assertive leader true to his words and intentions.

He is not swayed by the whims of public opinion as his predecessor was. Scrapping the fuel subsidy was an action the significance of which has been somewhat overlooked.

The fact that it did not create a huge uproar, in spite of its perception as a Pandora's Box by previous presidents, shows that Jokowi's leadership and political capital are greater than any other president since the beginning of reformasi.

That said, his rejection of clemency for death-row inmates and today's line-up of executions is not uncharacteristic of his leadership.

Many of his policies and actions in these past three months, excluding the "bigmother" drama alluding to the influence of his patron, speak of a leader who is not easily pressured by either domestic public opinion or international pressure.

Jokowi has shown that to some extent he has tunnel vision, concrete and measurable goals that fit his rather narrowly defined goals and vision.

He saw the need to reallocate money to support his infrastructure build-up and health and security protection programs.

Hence, he was prepared to risk a tidal wave of public uproar.

The same thing can be said of his leadership of Indonesia vis-a-vis other countries and the international community. Jokowi is not a hyper-nationalist leader who would 
ferment nationalism against other countries to garner public support or show himself as a "man of the people".

But nor will he cave in to international pressure if, in his calculation, it is not beneficial for his measurable goals to do so. He is not a friend to a million strangers like his predecessor, as clear from the recent executions of foreigners and sinking of illegal fishing ships.

The saving of any of the lives in the second execution roll-call, in particular the lives of the much-publicized two Australians is now a forlorn hope.

The fact that the first batch of executions included foreign citizens, exempting just the two Australians would be perceived as a double standard and as peculiar subservience to Australia.

In light of rows between the two nations over issues including Australia's obstinacy on boat people and the lack of apology for the wire-tapping incident, it is particularly tricky for the Australian government to lobby for the lives of Chan and Sukumaran.

It is lamentable that the Indonesian government, backed by overwhelming public opinion, looks likely to continue with the executions.

It is particularly sad to see that of the convicts in the next batch, Martin Anderson from Ghana, waiting to be executed for possession of a mere 50 grams of heroin.

It seems probably that President Jokowi's stubborn stance on executions, in spite of the international outcry and the constitutional provision for the right to life, is down to the advice he is getting.

He is likely being supplied with data and statistics on the drug problem plaguing Indonesian society. It is thus only logical in his mind to go ahead with the executions.

Advocates against the death penalty will need to be able to connect their arguments to concrete and measurable goals within Jokowi's programs.

They will also need to be able to show a clearer picture how the death penalty, as well as being prone to error, is also very unfairand can create a mess of the Indonesian justice system.

One clear contrast is the execution of Anderson with the perfunctory sentences of between three and six months in prison for the killers of three Ahmadi villagers in Cikeusik, Banten, in 2011 - an outrageous disparity. 
164 Celt, Volume 15, Number 2, December 2015, pp. 134-164

The conclusion: abolish the death penalty to allow time to rethink and review the fairness of the sentences.

Foreign countries understandably need to lobby for the lives of their citizens, but this will prove futile if it means Jokowi having to show preferential treatment to certain countries, which he will probably not do.

Foreign diplomats will need to help human rights activists frame the issue in the larger context and articulate how an end to the death penalty is in Indonesia's interests.

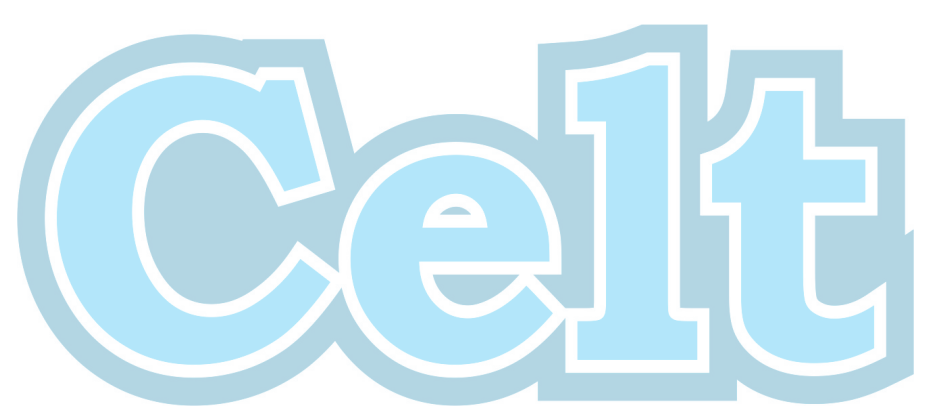

